H.influenzae (23.5\%), M.catarrhalis (15.1\%). Đặc biệt S.pneumonia là vi khuẩn gây bệnh ở mọi nhóm tuổi chiếm tỉ lệ cao.

\section{TÀI LIÊU THAM KHẢO}

1. Lưu Thị Thùy Dương (2019), Đăc điểm lâm sàng, cận lâm sàng và một số yếu tố liên quan đến mức độ nặng của viêm phổi ở trẻ từ 2 - 36 tháng tại bệnh viện Trung ương Thái Nguyên, Luận văn bác sỹ̃nội trú, Đaii học Y Dược Thái Nguyên.

2. Nguyễn Thị Hà, Đoàn Mái Thanh và Nguyễn Thi Yến (2020), "Đắc điểm lâm sàng và căn nguyên gây viêm phổi cộng đồng tại Khoa Quốc tế Bệnh viện Nhi Trung Ương", Tạp chí nghiên cứu Y hoc. 131(7), tr. 67-73.

3. Phạm Thị Thanh Tâm và Lê Thanh Hải Phùng Thị Bích Thủy (2021), "Tỷ lệ nhiễm một số vì khuẩn, virus ở trẻ viêm phổi tái diễn có suy hô hấp tai Bệnh viện Nhi Trung ương", Tạp chí Nghiên cứu và Thực hành Nhi khoa. 5(1).

4. Lê Văn Tráng (2016), "Nghiên cứu căn nguyên gây bệnh và yếu tố nguy cơ ở trẻ em bị viêm phổi kéo dải trên 2 tuần tai khoa hô hấp bệnh viên Nhi Thanh Hóa ", Tap chí Nghiên cứu và Thực hành Nhi khoa, tr. 58-64.

5. Mathew JL, Singhi S. Ray $P$ và et al (2015), "Etiology of community acquired pneumonia among children in India: prospective, cohort study", Journal of global health. 5(2).

6. Benet T., Sanchez P.V. Messaoudi M. và et al (2017), "Microorganisms Associated With Pneumonia in Children $<5$ Years of Age in Developing and Emerging Countries: The GABRIEL Pneumonia Multicenter, Prospective, Case-Control Study", Clin Infect Dis. 65(4), tr. 604-612.

7. Self $W$. H, Williams D. J. Zhu $Y$. và et al (2016), "Respiratory Viral Detection in Children and Adults: Comparing Asymptomatic Controls and Patients With Community-Acquired Pneumonia. ", J Infect Dis 2016, tr. 213 - 584.

8. WorldHealth Organization (2019), "Pneumonia" https://www.who.int/en/news-room/factsheets/detail/pneumonia

\title{
NGHIÊN CỨU ĐĂC ĐIỂM GIẢI PHẪU BỆNH U LYMPHO TẾ BÀO B XÂM NHẬP TỦY XƯƠ'NG
}

\section{TÓM TẮT}

Đă̆t vấn đề: Đánh giá tình trạng tủy xương đóng vai trò quan trọng trong phân chia giai đoạn u lympho, giúp tiên lượng cũng như lựa chọn phương pháp điêu trị. Muc tiêu: Khảo sát tỉ lệ và đăc điểm mô học tủy xương các trường hợp u lympho tế bào $B$ xâm nhập tủy xương. Đối tượng và phương pháp: Nghiên cứu mô tả cắt ngang các trường hợp u lympho tế bào $B$ tại Bệnh viện Truyền máu Huyết học từ tháng 01/2019 đến tháng 12/2020. Kết quả: Tỉ lệ u lympho tế bào $\mathrm{B}$ xâm nhâp tủy xương là $64,8 \%$. 40\% trướng hợp u lympho tế bào $B$ độ ác cao và $80 \%$ trường hợp u lympho tế bào $B$ độ ác thấp xâm nhập tủy xương. $\mathrm{LPL}$ và $\mathrm{BL}$ có tỉ lệ xâm nhập tủy xương cao nhất $(100 \%)$, thấp nhất là $\operatorname{DLBCL}(25,6 \%)$. Hình thái xâm nhập thường gặp nhất là dạng lan tỏa $(53 \%)$, tiếp theo là dạng hôn hợp (31\%). Dạng cạnh bè xương ghi nhận trong $50 \%$ FL và $10 \%$ DLBCL (FL chuyển dạng DLBCL). Dạng trong mạch máu trong xoang 0\%. 72,2\% MZL xâm nhập kiểu hỗn hợp. Kết luận: U lympho tế bào $B$ độ ác thấp có tỉ lệ xâm nhập tủy xương cao hơn u lympho tế bào $B$ đô ác cao. Hình thái xâm nhập tủy xương thường gặp nhất là dạng lan tỏa.

Tư khóa: U lympho tế bào $B$, dạng canh bè xương, dạng khu trú ngẫu nhiên, dạng mô kẽ், dạng trong mạch máu trong xoang, dạng hỗn hợp.

*Bệnh viện Truyền máu - Huyết học

**Đại học Y dược Thành phố Hồ Chí Minh

Chịu trách nhiệm chính: Tiêu Ngọc Kim Ngân

Email: kimnganbth1994@gmail.com

Ngày nhân bài: 4.6.2021

Ngày phản biên khoa hoc: 2.8.2021

Ngày duyệt bài: 11.8.2021

\section{SUMMARY \\ THE CHARACTTERISTICS OF B-CELL LYMPHOMAS INVOLVEMENT IN THE BONE MARROW}

Introduction: Bone marrow examination is an integral part of the clinical staging of lymphoma, also prognosis and therapeutic strategies. Objective: This study aimed to evaluate the incidence and characteristics of bone marrow involvement of B-cell lymphoma on trephine biopsy. Subjects and Methods: Cross section description of B-cell lymphoma from January 2019 to December 2020 at Blood Transfusion Hematology Hospital. The incidence and pattern of bone marrow involvement were analyzed. Results: The frequency of bone marrow involvement of B-cell lymphomas was $64.8 \%$. Bone marrow involvement was present in $80 \%$ of low-grade B-cell lymphomas, and $40 \%$ of high-grade variants. The highest incidence of bone marrow involvement was seen in $\mathrm{LPL}$ and $\mathrm{BL}(100 \%)$ and the lowest was found in DLBCL (25.6\%). Diffused pattern of infiltration was predominant (53\%), followed by mixed pattern (31\%). Typical bone marrow involvement in $50 \% \mathrm{FL}$ and $10 \%$ DLBCL (transformed FL to DLBCL) was characterized by paratrabecular infiltration. Intrasinusoidal infiltration was not detected. The most frequent pattern was mixed pattern $(72.2 \%)$ found in MZL. Conclusion: The frequency of bone marrow involvement of low-grade B-cell lymphomas was higher than high-grade variants. The pattern of diffuse infiltration was predominantly. Keywords: B-cell lymphoma, paratrabecular infiltration, random focal infiltration, diffuse infiltration, interstitial infiltration, intrasinusoidal infiltration, mixed infiltration 


\section{I. ĐĂT VẤN ĐỀ}

U lympho là một nhóm bênh lý ác tính của mô lympho rất đa dạng về biểu hiện lâm sàng, hình thái học, kiểu hình miễn dịch, di truyền tế bào, tiên lượng cũng như mức độ đáp ứng với các liệu pháp điều trị. Hiện nay phân loại của Tổ chức y tế thế giới về u hệ tạo máu và mô lympho cập nhật năm 2016 (WHO 2016) đã trở thành hệ thống phân loại quốc tế được chấp thuận rộng rãi. WHO 2016 phân chia bềnh lý ác tính dò̀ng lympho trưởng thành thành 3 nhóm lớn gồm u lympho tế bào $B$, u lympho tế bào T/NK và $u$ lympho Hodgkin. Trong đó u lympho tế bào $B$ là thể bệnh chiếm tỉ lê cao nhất. U lympho có thể xâm nhập đến nhiều cơ quan ngoài hạch, trong đó tủy xương là vị trí phổ biến nhất. Sinh thiết tủy xương không thể tiến hành nhiều vị trí, do đó chúng ta chấp nhận kết quả tại một vị trí (thường là xương chậu) sẽ có giá trị phản ánh cho tình trạng toàn bộ tủy xương. Một số nghiên cứu cho thây Chụp cộng hưởng từ (MRI) và Chụp cắt lớp điện toán đồng vị phóng xạ positron (PET-CT) cho kết quả vượt trội hơn so với phương pháp sinh thiết tủy xương truyền thống. Ngoài ra MRI và PET-CT có thể xác định các trường hợp u lympho xâm nhập tủy xương ở vị trí khác xương chậu. Mặc dù MRI và PET-CT có độ nhạy cao nhưng độ đặc hiệu không cao trong đánh giá u lympho xâm nhập tủy xương. Sinh thiết tủy xương vẫn được xem là tiêu chuẩn vàng. U lympho xâm nhập tủy xương tương ứng bệnh ở giai đoạn IV theo phân loại Ann Abor và tăng chỉ số tiên lượng quốc tế (IPI), ảnh hưởng đến chiến lược điêu trị cũng như tiên lượng bệnh. Do đó chúng tôi thực hiện nghiên cứu khảo sát tỉ lệ và đặc điểm mô học tủy xương các trường hợp u lympho tế bào $B$ xâm nhập tủy xương tại Bệnh viện Truyền máu Huyết học (BVTMHH).

\section{II. ĐỐI TƯỢNG VÀ PHƯƠNG PHÁP NGHIÊN CỨU}

Nghiên cứu mô tả hàng loạt ca, hồi cứu. Đối tượng nghiên cứu là các trường hợp chẩn đoán u lympho tế bào $B$ tại BVTMHH trong thời gian 24 tháng, từ $01 / 2019$ đến $12 / 2020$. Chọn các trường hợp bệnh mới chẩn đoán có đủ bằng chứng chẩn đoán xác định và có sinh thiết tủy xương. Loại trừ các trường hợp đã được điều trị đặc hiệu hoặc chẩn đoán u lympho tế bào $B$ nguyên phát tại tủy. Nhuộm Hematoxylin \& Eosin trên lát cắt mẫu sinh thiết thiết tủy xương có độ dày 2-3 $\mu \mathrm{m}$. Phân loại độ mô học và mô tả hình thái xâm nhập tế bào u. Phân loại độ mô học gồm 2 nhóm: (1) U lympho độ ác thấp: bệnh diễn tiến chậm, gồm các u lympho tế bào kích thước nhỏ (FL, CLL/SLL, LPL, MCL, MZL); (2) U lympho độ ác cao: bệnh diễn tiến nhanh, gồm các lymphôm tế bào kích thước trung bình lớn ( $D L B C L, H G B L, B L, M C L$ biến thể tế bào non). Hình thái xâm nhập tế bào u được phân thành 6 nhóm: (1) Mô kẽ: tế bào u nằm xen kẽ giữa các tế bào tạo máu, cấu trúc tủy xương vẫn còn; (2) Nốt khu trú: tế bào u nằm khu trú dạng nốt, xen lẫn với các tế bào tạo máu, không nằm cạnh bè xương; (3) Cạnh bè xương: tế bào u nằm ngay sát bè xương; (4) Lan tỏa: tủy xương mất cấu trúc bình thường, cả tế bào tạo máu và tế bào mõ đều được thay thế bởi tế bào u; (5) Trong mạch máu, trong xoang: tế bào u nằm phân tán trong các xong tủy và xoang mạch máu; (6) Hỗn hợp: xuất hiện đồng thời $\geq 2$ hình thái xâm nhập khác nhau. Phân tích và xử lý số liệu bằng phần mềm Excel.

\section{KẾT QUẢ NGHIÊN CỨU}

Tỉ lệ u lympho tế bào $B$ xâm nhập tủy xương là $64,8 \%$ (79/124 trường hợp). U lympho tế bào $B$ độ ác thấp có tî lệ xâm nhập tủy xương cao hơn u lympho tế bào $\mathrm{B}$ độ ác cao, $80 \%$ và $40 \%$ (59/74 trường hợp u lympho tế bào $B$ độ ác thấp và 20/50 trường hợp u lympho tế bào $B$ độ ác cao) Tỉ lệ xâm nhập tủy xương của u lympho Burkitt $(\mathrm{BL})$ và u lympho tương bào lympho bào/ bệnh đại phân tử globulin Waldenstrom (LPL/WM) là cao nhất $100 \%$ (6/6 trường hợp $\mathrm{BL}$ và $8 / 8$ trường hợp $L P L / W M)$. Thấp nhất là $u$ lympho tế bào $B$ lớn lan tỏa (DLBCL) $25,6 \%$ (10/39 trường hợp). (Biểu đồ 1 )

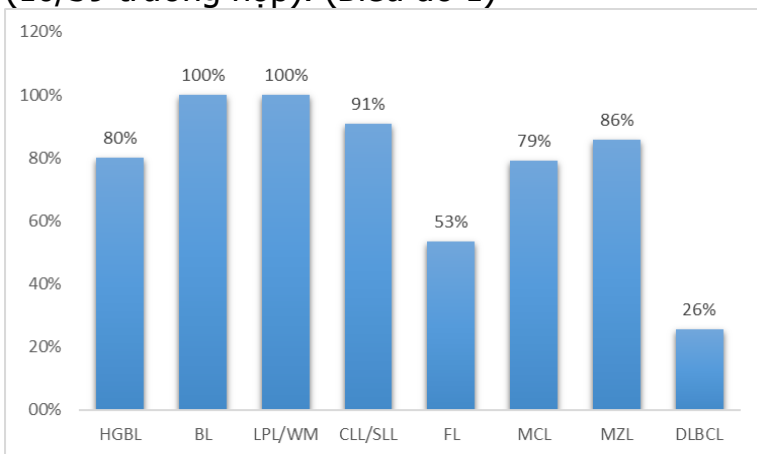

Biểu đồ 1. Tỉ lệ xâm nhập tủy xương từng phân nhóm u lympho tế bào B

Hình thái xâm nhập lan tỏa thường gặp nhất $53 \%$ (42/79 trường hợp). Phổ biến hàng thứ hai là dạng hỗn hợp 31\% (26/79 trường hợp). Dạng cạnh bè xương, dạng mô kẽ và dạng nốt chiếm tỉ lệ thấp, theo thứ tự $6 \%, 6 \%$ và $1 \%$ (5/79 trường hợp, 5/79 trường hợp và 1/79 trường hợp). Không ghi nhận hình ảnh xâm nhập trong mạch 
máu trong xoang trên lam nhuộm H\&E.

Trong nhóm u lympho tế bào $B$ độ ác thấp, hình ảnh xâm nhập dạng cạnh bè xương chỉ ghi nhận trong u lympho nang (FL), dạng mô kẽ chỉ ghi nhận trong u lympho tế bào áo nang $(\mathrm{MCL})$, dạng nốt chỉ ghi nhận trong bệnh bạch câuu mạn dòng lympho/u lympho tế bào lympho nhỏ (CLL/SLL), dạng lan tỏa và dạng hỗn hợp không đặc hiệu, có thể gặp ở mọi phân nhóm. 54,2\% (14/26 trường hợp) xâm nhập dạng hỗn hợp là u lympho vùng rìa (MZL). (Bảng 1 )

Trong nhóm u lympho tế bào $B$ độ ác cao, không ghi nhận trường hợp $\mathrm{MCL}$ biến thể tế bào non, hình ảnh xâm nhập dạng cạnh bè xương chỉ ghi nhận trong DLBCL (được chẩn đoán FL chuyển dạng $D L B C L)$. Dạng mô kẽ chỉ ghi nhận trong DLBCL và HGBL. Không ghi nhận dạng nốt. Dạng lan tỏa không đặc hiệu có thể gặp trong $B L$, $H G B L$ và $D L B C L$, dạng hỗn hợp chỉ ghi nhận trong DLBCL. (Bảng 1).

Bảng 1 Phân bố hình thái xâm nhập tủy xương từng phân nhóm u lympho tê bào B

\begin{tabular}{|c|c|c|c|c|c|c|c|c|c|c|c|c|}
\hline & \multicolumn{2}{|c|}{$\begin{array}{c}\text { Cạnh bè } \\
\text { xương }\end{array}$} & \multicolumn{2}{|c|}{$\begin{array}{l}\text { Trong mạch } \\
\text { máu, trong } \\
\text { xoang }\end{array}$} & \multicolumn{2}{|c|}{ Mô kẽ } & \multicolumn{2}{|c|}{ Nốt } & \multicolumn{2}{|c|}{ Lan tỏa } & \multicolumn{2}{|c|}{ Hỗn hợp } \\
\hline \multicolumn{13}{|c|}{ U lympho tế bào B độ ác cao } \\
\hline $\begin{array}{l}\mathrm{HGBL} \\
(\mathrm{n}=4)\end{array}$ & 0 & $0,0 \%$ & 0 & $0,0 \%$ & 1 & $25,0 \%$ & 0 & $0,0 \%$ & 3 & $75,0 \%$ & 0 & $0,0 \%$ \\
\hline $\begin{array}{c}B L \\
(n=6)\end{array}$ & 0 & $0,0 \%$ & 0 & $0,0 \%$ & 0 & $0,0 \%$ & 0 & $0,0 \%$ & 6 & $100,0 \%$ & 0 & $0,0 \%$ \\
\hline $\begin{array}{c}\text { MCL blastoid } \\
(n=0)\end{array}$ & 0 & $0,0 \%$ & 0 & $0,0 \%$ & 0 & $0,0 \%$ & 0 & $0,0 \%$ & 0 & $0,0 \%$ & 0 & $0,0 \%$ \\
\hline $\operatorname{DLBCL}(n=10)$ & 1 & $10,0 \%$ & 0 & $0,0 \%$ & 2 & $20,0 \%$ & 0 & $0,0 \%$ & 5 & $50,0 \%$ & 2 & $20,0 \%$ \\
\hline \multicolumn{13}{|c|}{ U lympho tế bào B đô ác thấp } \\
\hline LPL/WM $(n=8)$ & 0 & $0,0 \%$ & 0 & $0,0 \%$ & 0 & $0,0 \%$ & 0 & $0,0 \%$ & 7 & $87,5 \%$ & 1 & $12,5 \%$ \\
\hline $\mathrm{CLL} / \mathrm{SLL}(\mathrm{n}=10)$ & 0 & $0,0 \%$ & 0 & $0,0 \%$ & 0 & $0,0 \%$ & 1 & $10,0 \%$ & 7 & $70,0 \%$ & 2 & $20,0 \%$ \\
\hline $\begin{array}{c}\mathrm{FL} \\
(\mathrm{n}=8)\end{array}$ & 4 & $50,0 \%$ & 0 & $0,0 \%$ & 0 & $0,0 \%$ & 0 & $0,0 \%$ & 2 & $25,0 \%$ & 2 & $25,0 \%$ \\
\hline $\begin{array}{c}\mathrm{MCL} \\
(n=15)\end{array}$ & 0 & $0,0 \%$ & 0 & $0,0 \%$ & 2 & $13,3 \%$ & 0 & $0,0 \%$ & 7 & $46,7 \%$ & 6 & $40,0 \%$ \\
\hline $\begin{array}{c}\text { MZL } \\
(n=18)\end{array}$ & 0 & $0,0 \%$ & 0 & $0,0 \%$ & 0 & $0,0 \%$ & 0 & $0,0 \%$ & 5 & $27,8 \%$ & 13 & $72,2 \%$ \\
\hline
\end{tabular}

Hình thái xâm nhập tủy xương dạng lan tỏa ghi nhận trong $70 \%$ u lympho tế bào $\mathrm{B}$ độ ác cao (14/20 trường hợp) và trong $48 \%$ u lympho tế bào $B$ độ ác thấp (28/59 trường hợp). (Bảng 1 và Hình 1)

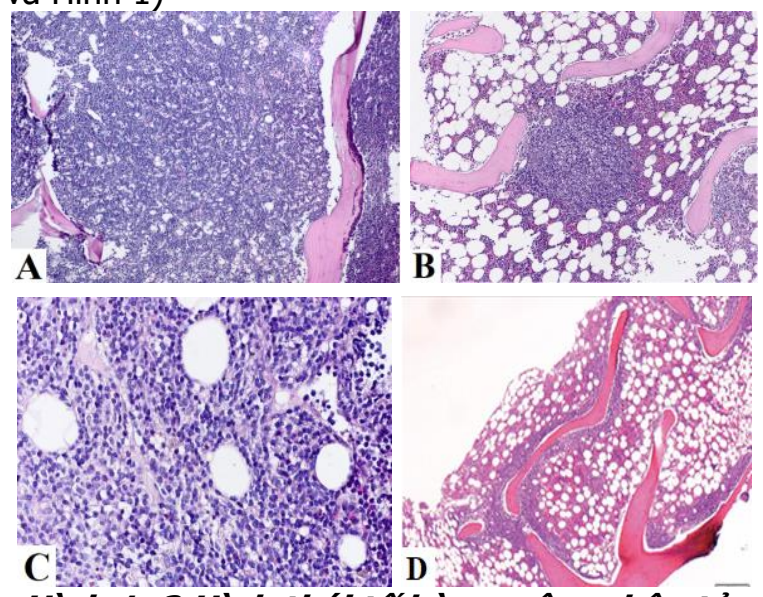

Hình 1. 2 Hình thái tế bào u xâm nhập từy xương trên lam nhuộm H\&E

(A) Tế bào $\mathrm{BL}$ xâm nhập tủy xương dạng lan tỏa (Mã số 0522/2020, H\&E x100). (B) Tế bào
MZL xâm nhập xương tủy dạng nốt (Mã sỗ 0438/2020, H\&E x100). (C) Tế bào CLL/SLL xâm nhập tủy xương dang lan tỏa (Mã số 0253/2020, H\&E x400). (D) Tế bào FL xâm nhập tủy xương dạng cạnh bè xương (Mã số 0189/2020, H\&E x40).

\section{BÀN LUÂN}

Theo nghiên cứu của tác giả LambertenghiDeliliers ghi nhận tỉ lệ xâm nhập tủy là khoảng $40 \%$ [4]. Nghiển cứu của chúng tôi là $64,8 \%$. Các trường hợp chẩn đoán u lympho tại Việt Nam đa số ở giai đoạn muộn làm tăng tỉ lệ xâm nhập tủy xương - một trong những đặc điểm bênh lan tràn. U lympho tế bào $B$ độ ác thấp có tỉ lệ xâm nhập tủy xương cao hơn u lympho tế bào $\mathrm{B}$ độ ác cao (80\% so với $40 \%)$.

Trong nhóm $\mathrm{u}$ lympho tế bào $\mathrm{B}$ độ ác cao, HGBL do là thể bênh mới được cập nhật ở WHO 2016 nên chưa được ghi nhận ở các nghiên cứu trước đó. Nghiên cứu chúng tôi ghi nhận $80 \%$ trường hợp HGBL xâm nhập tủy xương. Nghiên cứu của tác giả Jack và tác giả Brunning cho thấy tỉ lệ $\mathrm{BL}$ xâm nhập tủy xương là $45 \%$ và $85 \%$ [2]. Nghiên cứu của chúng tôi cho thấy BL có tỉ lệ xâm 
nhập tủy xương 100\%. Nghiên cứu của tác giả Yao cho thấy DLBCL tỉ lệ xâm nhập tủy xương $37 \%$ [8]. Nghiên cứu của chúng tôi là $26,0 \%$.

Trong nhóm u lympho tế bào $B$ độ ác thấp, LPL/WM có tỉ lệ xâm nhập tủy xương đạt $100 \%$ [5], [6]. Đặc điểm này phù hợp với nghiên cứu của chúng tôi. Nghiên cứu chúng tôi ghi nhận $91 \%$ trường hợp CLL/SLL và $53 \% \mathrm{FL}$ xâm nhập tủy xương. Đồng thời chúng tôi cũng ghi nhận $79 \%$ trường hợp $\mathrm{MCL}$ và $86 \%$ trường hợp $\mathrm{MZZL}$ xâm nhập tủy xương.

Theo nghiên cứu của tác giả Hassan u lympho tế bào $B$ xâm nhập tủy xương dạng lan tỏa chiếm $77,5 \%$, dạng nốt $12,5 \%$ và dạng cạnh bè xương 10\%; không ghi nhận dạng mô kẽ, trong mạch máu trong xoang và dạng hỗn hợp [3]. Theo tác giả Arber, kiểu xâm nhập dạng hỗn hợp thường gặp nhất, chiếm 46,4\%. Các kiểu xầm nhập mô kẽ, cạnh bè xương, nốt khu trú và lan tỏa chiếm tỉ lệ khá tương đồng, dao động từ $9,3-15,8 \%$. [1]. Theo nghiên cứu của chúng tôi, hình ảnh xâm nhập lan tỏa thường gặp nhất chiếm $53,0 \%$. Phổ biển hàng thứ hai là dạng hỗn hợp chiếm 31,3\%.

HGBL là thể bệnh mới được bổ sung trong WHO 2016 nên chưa được nghiên cứu nhiều. Theo nghiên cứu của chúng tôi ghi nhận đa số các trường hợp kiểu lan tỏa chiếm $75 \%$, chỉ có $25 \%$ dạng mô kẽ. Hầu hết nghiên cứu BL xâm nhập kiểu lan tỏa [1], [7]. Đặc điểm này phù hợp với nghiên cứu của chúng tôi. Nghiên cứu của tác giả Arber [1] và nghiên cứu của chúng tôi đều ghi nhận DLBCL xâm nhập kiểu lan tỏa là thường gặp nhất.

Theo y văn LPL/WM hình thái xâm nhập đa dạng [5]. Theo nghiên cứu của chúng tổi ghi nhận đa số các trường hợp LPL/WM xâm nhâp kiểu lan tỏa chiếm $88 \%$, chỉ có $12 \%$ dạng hổn hợp. FL thường xâm nhập dạng cạnh bè xương, tuy nhiên những dạng khác cũng có thể gặp như dạng khu trú hoặc lan tỏa [5]. Theo nghiên cứu của chúng tôi có $50 \%$ trường hợp FL có hình ảnh xâm nhập dạng cạnh bè xương. Nghiên cứu của tác giả Shi cho thấy hầu hết CLL/SLL xâm nhập dạng nốt với $36 \%$ và dạng hỗn hợp với $41 \%$ [6]. Theo nghiên cứu của chúng tôi ghi nhận đa số các trường hợp CLL/SLL xâm nhập kiểu lan tỏa $70 \%$, chỉ có $20 \%$ dạng hỗn hợp và $10 \%$ dạng nốt. Theo nghiên cứu của chúng tôi, tác giả Arber và tác giả Shi với tỉ lệ $\mathrm{MCL}$ thường xâm nhập kiểu hỗn hợp lần lượt là $40 \%, 64 \%$ và $65 \%$ [1], [6]. Tương tự, theo nghiên cứu của chúng tôi, tác giả Arber và tác giả Shi đều ghi nhận hình thái xâm nhập kiểu hỗn hợp chiếm ưu thế trong MZL [1], [6].

\section{KẾT LUÂ̂N}

Đánh giá chính xác tình trạng tủy xương góp phần quan trọng trong lựa chọn phác đồ điêu trị cũng như tiên lượng bệnh. Hầu hết các hình thái xâm nhập mặc dù không đặc hiệu nhưng có vai trò quan trọng trong định hướng chẩn đoán, giúp làm giảm số lượng hóa mô miễn dịch được chỉ định. U lympho tế bào $B$ độ ác thấp có tỉ lệ xâm nhập tủy xương cao hơn u lympho tế bào $B$ độ ác cao. Hình thái xâm nhập tủy xương thường gặp nhất là dạng lan tỏa. Đa số MZL xâm nhập tủy dạng hốn hợp. Dạng xâm nhập cạnh bè xương đặc trưng cho FL.

Từ viết tắt: $D L B C L$ U lympho tế bào $B$ lớn lan tỏa; MZL U lympho vùng rìa; MCL U lympho tế bào áo nang; FL U lympho nang; CLL/SLL Bệnh bạch cầu mạn dòng lympho /U lympho tế bào lympho nhỏ; LPL/WM U lympho tương bào lympho bào/ Bệnh đại phân tử globulin Waldenstrom; BL U lympho Burkitt; HGBL U lympho tế bào B độ ác cao; WHO 2016 Phân loại của Tổ chức y tế thế giới về u hê tạo máu và mô lympho câp nhật năm 2016; MRI Chụp cộng hưởng từ; PET-CT Chụp cắt lớp điện toán đồng vị phóng xạ positron.

\section{TÀI LIÊU THAM KHẢO}

1. Arber D. A. , George T. I. (2005), "Bone marrow biopsy involvement by non-Hodgkin's lymphoma: frequency of lymphoma types, patterns, blood involvement, and discordance with other sites in 450 specimens", The American journal of surgical pathology. 29 (12), pp. 1549-1557.

2. Brunning R. D., McKenna R. W., Bloomfield C. D. et al. (1977), "Bone marrow involvement in Burkitt's lymphoma", Cancer. 40 (4), pp. 17711779.

3. Hassan K., Ikram N., Bukhari K. P. et al. (1995), "The Pattern of Bone Marrow Infiltration in Non-Hodgkin's Lymphornas", .

4. Lambertenghi-Deliliers G., Ánnaloro $C_{\text {., }}$ Soligo D. et al. (1992), "Incidence and histological features of bone marrow involvement in malignant lymphomas", Annals of hematology. 65 (2), pp. 61-65.

5. Orazi A., Foucar K., Knowles D. et al. (2013), "Knowles neoplastic hematopathology", Lippincott Williams \& Wilkins, pp. 399-583.

6. Shi Y. F., Li X. H., Song Y. Q. et al. (2015), "Involvement of bone marrow in lymphoma: pathological investigation in a single-center from northern China", International journal of clinical and experimental pathology. 8 (6), pp. 7102.

7. Swerdlow S. H., Campo E., Harris N. L. et al. (2016), "WHO Classification of Tumours of Haematopoietic and Lymphoid Tissues", pp. 216-344.

8. Yao Z., Deng L., Xu-Monette Z. Y. et al. (2018), "Concordant bone marrow involvement of diffuse large B-cell lymphoma represents a distinct clinical and biological entity in the era of immunotherapy", Leukemia. 32 (2), pp. 353-363. 